\title{
The Effect Of Directors And Officers Liability Insurance On Audit Effort
}

Sohee Woo, Yonsei University, South Korea

Chang Seop Rhee, Sejong University, South Korea

Sanghee Woo, Sungkyunkwan University, South Korea

\begin{abstract}
This study investigates the effect of directors and officers liability insurance (hereafter, $D \& O$ liability insurance) on audit effort of auditors. $D \& O$ liability insurance is a liability insurance payable to top executives of a company as indemnification for losses or litigation costs from the lawsuits. Companies carry $D \& O$ liability insurance for the purpose of protecting their directors and officers from the legal actions. However, according to prior studies, the managers of their companies with D\&O liability insurance may become more risk seeker, and they take more risks for their decision. If D\&O liability insurance causes more risks at the company, auditors for the companies may use the information of $D \& O$ liability insurance as a risk factor at the audit engagement. This study examines whether D\&O liability insurance has a significant influence audit effort of auditors empirically. We use the mandatory disclosed Korean data of D\&O liability insurance for testing the association between D\&O liability insurance and audit effort. From the results, we find that auditors use D\&O liability insurance information for setting the amount of audit effort. Also, both Big4 and Non-Big4 use D\&O liability insurance as useful information.
\end{abstract}

Keywords: Directors And Officers Liability Insurance; Audit Effort; Audit Hours, Audit Fees

\section{INTRODUCTION}

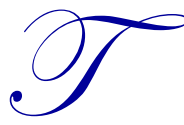

his paper investigates the effect of directors and officers liability insurance (D\&O liability insurance) on audit effort of auditors. D\&O Liability insurance is a liability insurance payable to top executives of a company as indemnification for losses or litigation costs from the lawsuits, and companies carry $\mathrm{D} \& \mathrm{O}$ liability insurance for protecting their directors and officers from the lawsuits. Therefore, D\&O liability insurance is a safeguard to cover the monetary damage from litigation risks. However, carrying D\&O liability insurance causes that managers become less risk averse. They are also less likely to reject attractive new risky projects with D\&O liability insurance (Core, 1997). Moreover, in the case of abusing the insurance, managers may take more risks and exhibit more opportunism than managers without D\&O liability insurance. Previous studies provide evidence that managers of companies with $\mathrm{D} \& \mathrm{O}$ liability insurance have more opportunity to engage in earnings management (Narjess, Nabil, and Martin, 2008). Also, in general, earnings management is more likely to occur in insured corporations than in uninsured corporations. In this circumstance, auditors may consider whether their clients are insured or uninsured as useful information for estimating clients' audit risks. If auditors use the information of $\mathrm{D} \& \mathrm{O}$ liability insurance for considering that insured companies have higher potential litigation risk than uninsured companies, there is a positive association between D\&O liability insurance and audit effort. To test the association, we uses audit hours and audit fees as proxies for audit effort.

Especially, Korean financial market provides a good research setting to examine the effect of D\&O liability insurance on audit effort. First, D\&O liability insurance is available in Korean setting because only Korean companies are required to disclose D\&O liability insurance mandatorily until 2008 except Canada and Tawian companies. Next, since the establishment of the Securities Class Act in 2007, more than one third of Korean public companies carry D\&O liability insurance and the demand of D\&O liability insurance is sharply increased in Korea. Last, a few countires are required to disclose audit hours, but Korean companies are required to disclose both audit hours and audit fees to the public (Chun and Rhee, 2015). For the above reasons, Korean finanical market is an appropriate setting to investigate the effect of D\&O liability on audit effort. 
This study contributes to the literature in the following ways. First, to our knowledge, there is no previous evidence on the direct positive association between D\&O liability insurance and audit effort in Korea. This empirical evidence may shed a light on our understanding of managers' incentives on D\&O liability insurance. Second, this study provides insight into auditors' belief about D\&O liability insurance. Third, this study provides evidence that $\mathrm{D} \& \mathrm{O}$ liability insurance information is very meaningful to auditors. However, in Korea, disclosing D\&O liability insurance information is not mandatory anymore after 2008. This study therefore suggests that policymakers should consider re-mandatory public disclosure of D\&O liability insurance information for the market participants.

Using 2,026 Korean firm-year observations during 2005 to 2008 period, this study finds that there is a positive association between D\&O liability insurance and audit effort. It implies that auditors input more audit hours and charge more audit fees to the companies with D\&O liability insurance than the companies without the insurance. Also, audit hours and audit fees are increased as the insurance coverage limit of D\&O liability insurance is higher. The empirical results suggest that auditors use D\&O liability insurance as useful information for evaluating their clients' audit risk.

The remainder of this paper is as follows. In Section 2, background information and developing hypotheses are introduced. In Section 3, the sample and the research method are described and in section 4, our empirical findings are presented. Finally, in section 5, conclusions and implications from the findings are drawn.

\section{BACKGROUND AND HYPOTHESES DEVELOPMENT}

Recently, many corporations have become concerned about the possibility of lawsuits from investors and outside parties. For the reason, more companies began to carry the D\&O liability insurance. D\&O liability insurance is a method by which top executives of the company protects themselves or their organizations from damage or defense costs due to criminal, civil, or administrative legal action. As a study of D\&O liability insurance, Tillinghast (2002) reports that approximately $19 \%$ of U.S. survey respondents experienced more than one claims against their companies' directors for a 10-year working periods, and all respondents' companies carried D\&O liability insurance. Thus, D\&O liability insurance is very common to U.S. public companies. In Korea, D\&O liability insurance has been adopted by a few companies since 1991, but it is not widespread because corporate litigation is not prevalent. However, since the establishment of the Securities Class Act in 2007, litigation against public companies in Korea has increased. Now, approximately $36 \%$ of Korean public companies carry D\&O liability insurance.

The main purpose of $\mathrm{D} \& \mathrm{O}$ insurance is to protect top executives of the company. However, when a company carries the insurance, it may affect managers' opportunistic behaviors. Core (1997) reports that directors and officers become less risk averse. They are also less likely to reject attractive new risky projects. In this circumstance, by abusing the insurance, managers of insured companies can take more risks aggressively and exhibit more opportunism than managers of uninsured companies. Narjess et al. (2008) provide evidence that managers of companies with D\&O liability insurance have more opportunity to engage in earnings management. If auditors use the information of $\mathrm{D} \& \mathrm{O}$ liability insurance for setting the amount of audit effort, there will be a positive association between D\&O liability insurance and audit effort. In this study, audit hours and audit fees are used as proxies for audit effort. To investigate the association between D\&O liability insurance and audit effort, we set the following hypothesis:

H1: There is a positive association between audit effort and carrying D\&O insurance.

Managers choose insurance coverage limits depending on their litigation risk. When companies are at high risk of litigation, they select higher insurance coverage limits (Core, 1997; O'Sullivan, 2002; Fier, McCullough, Mansfield, and Gabel, 2012; Gillan and Panasian, 2014). When managers become entrenched or plan to invest in risky projects, they may extend their insurance coverage in order for maximum protection. We believe that the insurance coverage limit provides valuable information about the degree of litigation risk. Higher the insurance coverage limit of $\mathrm{D} \& \mathrm{O}$ insurance implies the higher the litigation risk. 
Auditors are concerned about litigation risk from financial failure of their clients and the litigation risk cannot be completely eliminated due to clients' business risk. Auditors determine the amount of their audit effort they will input using audit risk model (ARM). Unfortunately, the ARM model fails to capture the clients' business risk because it focuses on the risk of material misstatement rather than the risk of financial failure (Houston, Peters, and Pratt, 1999). We believe that the insurance coverage limit of D\&O liability insurance reflects overall risk occurring due to misstatement, financial failure, internal control problems, or corporate governance better than the ARM. Using the information, auditors can adjust their audit effort to reduce the audit risk.

Generally, companies consider their specific conditions such as level of litigation risks, financial status, and governance effects for purchasing D\&O insurance. Thus, companies with $\mathrm{D} \& \mathrm{O}$ insurance may have different characteristics from companies without $\mathrm{D} \& \mathrm{O}$ insurance companies, and there may be a possibility of selection bias from total sample. Therefore, we sort the total sample into two groups: insured companies and uninsured companies. Then, we exclude uninsured companies to prevent the selection bias and examine the effect of D\&O insurance using insured companies only. We state the following hypothesis:

H2: There is a positive association between the insurance coverage limit of $\mathrm{D} \& \mathrm{O}$ insurance and audit effort.

\section{RESEARCH METHODOLOGY}

\subsection{Sample Selection}

The sample of companies in this study consists of Korean listed companies from 2005 to 2008 for which information about audit hours, audit fees, financial status, and D\&O liability insurance coverage are available. To increase comparability, it selects companies that satisfy the following criteria (1) financial statement data with positive book value of equity available on the Korea Information Services Value (KIS-VALUE) database; (2) all of the proxies are available; (3) firms in non-financial industry; (4) fiscal year ended December 31. Financial data was collected from the Korea Information Services Value (KIS-VALUE) database and information about audit hours, fees, and D\&O liability insurance were manually collected from each company's audit reports and annual reports from the Data Analysis, Retrieval and Transfer System of the Financial Supervisory Service (http:// dart.fss.or.kr). This process yields final sample of 2,026 annual firm-year observations. Table 1 shows the sample distribution of the final firm-year observations for the empirical tests.

Table 1. Sample distribution

\begin{tabular}{|c|c|c|c|}
\hline Year & Total sample firms & Insured-companies & Ratio of insured-company \\
\hline 2005 & 412 & 136 & $33.01 \%$ \\
\hline 2006 & 519 & 183 & $35.26 \%$ \\
\hline 2007 & 535 & 197 & $36.82 \%$ \\
\hline 2008 & 560 & 213 & $38.04 \%$ \\
\hline Total & 2,026 & 729 & $35.98 \%$ \\
\hline
\end{tabular}

\subsection{Hypothesis Testing}

used.

To investigate the association between D\&O liability insurance and audit effort, the following model is

\section{Model (1):}

AUDIT EFFORT $=\beta_{0}+\beta_{1} D \& O(L C O V \quad)+\beta_{2} B I G 4+\beta_{3} S I Z E+\beta_{4} R O A+\beta_{5} L E V+\beta_{6} L O S S+\beta_{7} I N V R E C+\beta_{8}$ EXPRATIO + $\beta_{9} D A+$ Year_Dummies + Industry_Dummies $+\varepsilon$ 
Where

\begin{tabular}{|c|c|}
\hline \multicolumn{2}{|c|}{ Dependent Variables } \\
\hline $\begin{array}{l}\text { AUDIT EFFORT } \\
(L H O U R \& L F E E)\end{array}$ & The natural log of audit hours (LHOUR) and the natural log of audit fees (LFEE). \\
\hline \multicolumn{2}{|l|}{ Key Variables } \\
\hline$D \& O$ & $\begin{array}{l}\text { An indicator variable that equals one when the company has D\&O liability insurance and zero } \\
\text { otherwise. }\end{array}$ \\
\hline$L C O V$ & Natural log of the insurance coverage limit of D\&O liability insurance \\
\hline \multicolumn{2}{|l|}{ Control Variables } \\
\hline BIG4 & An indicator variable that equals one when the audit firm is a Big4 auditor and zero otherwise. \\
\hline$S I Z E$ & Natural log of the total assets. \\
\hline$R O A$ & Return on assets; ratio of net income to total asset. \\
\hline$L E V$ & Total leverage scaled by total assets. \\
\hline LOSS & $\begin{array}{l}\text { An indicator variable that equals one when the company's net income is negative and zero } \\
\text { otherwise. }\end{array}$ \\
\hline INVREC & The sum of inventories and receivable divided by total assets. \\
\hline EXPRATIO & The ratio oversea sales to total sales. \\
\hline$D A$ & Absolute value of discretionary accruals calculated by Kothari et al. (2005). \\
\hline Year Dummy & Year dummy variables. \\
\hline Industry Dummy & Industry dummy variables. \\
\hline
\end{tabular}

To estimate audit effort, audit hours and audit fees are used(Reynold et al., 2004; Rhee et al., 2012). The dependent variables are the natural $\log$ of audit hours (LHOUR) and the natural log of audit fees (LFEE). The variable of primary interest in this study is D\&O insurance coverage. We assume that companies with D\&O liability insurance have higher litigation risk than companies without D\&O liability insurance. Therefore, the coefficient of the D\&O insurance variable is expected to be positive. The Model (1) includes control variables that affect audit effort. In general, Big4 auditors (BIG4) spend more time and charge higher audit fees due to their reputation (Palmrose, 1986). With an increase in size of the client firm, the audit and litigation risk against the audit firm also increases (St. Pierre and Anderson, 1984; Reynold and Francis, 2004). Variables representing profitability (ROA) and solvency ( $L E V$ and $L O S S$ ) are included, following the protocol in prior studies (Simunic, 1980; Reynold et al., 2001; Ashbaygh, LaFond and Mayhew, 2003; Ge and Mcvay, 2005; Doyle, Ge, and McVay, 2007). To control for the complexity of client firms, two variables, INVREC and EXPRATIO, are included. When values for INVREC and EXPRATIO increase, the need for observation and verification of audit procedures also increases (Choi and Baek, 1998; Park and Choi, 2009; Chun and Rhee, 2005). When earnings management is a strong possibility, as measured using the absolute value of discretionary accruals $(D A)$, auditors spend more time and charge higher audit fees. Finally, year and industry dummies are included to control for yearly and industry differences. To test hypothesis 2 , $L C O V$ is included as an independent variable instead of D\&O insurance coverage. Other variables for testing of hypothesis 2 are the same as in Model (1).

\section{EMPIRICAL RESULTS}

\subsection{Descriptive Statistics}

Panel A in Table 2 presents the descriptive statistics for all variables used in the full sample. The mean of the natural $\log$ of audit hours $(L H O U R)$ is 6.910. The mean of the natural log of audit fees (LFEE) is 18.303. The indicator variable, $\mathrm{D} \& \mathrm{O}$, has a mean value of 0.356 , implying that $35.6 \%$ of sample firms carry D\&O liability insurance. The mean of $B I G 4$ is 0.686 , indicating that $68.6 \%$ of sample firms are audited by Big 4 auditors. The mean of SIZE is 26.417 . The average return on assets $(R O A)$ is 0.032 . The mean of leverage $(L E V)$ is 0.443 . The indicator variable, $L O S S$, has a mean value of 0.189 , implying that $18.9 \%$ of sample firms have negative net income. The mean value for the ratio of the sum of inventory and accounts receivable to total assets (INVREC) is 0.274 , and the mean value for the ratio of overseas sales to total sales (EXPRATIO) is 27.688. The mean of the absolute value of discretionary accruals $(D A)$ is 0.057 . 
Additionally, Panel B in Table 2 provides the descriptive statistics of the variables used in insured companies. The mean values for LHOUR and LFEE are 7.512 and 18.870, respectively. The variable of interest, $L C O V$, has a mean value of 4.359 . In addition, $85.9 \%$ of insured companies are audited by Big4 auditors. The mean value for the size variable is 27.504 . The mean values for $R O A$ and $L E V$ are 0.018 and 0.167 , respectively. In addition, $15.4 \%$ of insured companies have negative net income. The mean values of INVREC and EXPRATIO are 0.231 and 32.467 , respectively. The mean value for $D A$ is 0.056 . All variables are winsorized at top and bottom $1 \%$ of the pooled data.

Table 2. Descriptive Statistics

Panel A: full sample

\begin{tabular}{lrccrc}
\hline \multicolumn{1}{c}{ Variable } & Mean & Q1 & Median & Q3 & Std. Dev. \\
\hline LHOUR & 6.910 & 6.380 & 6.780 & 7.279 & 0.825 \\
LFEE & 18.303 & 17.786 & 18.133 & 18.643 & 0.769 \\
D\&O & 0.357 & 0 & 0 & 1.000 & 0.479 \\
BIG4 & 0.686 & 0 & 1.000 & 1.000 & 0.464 \\
SIZE & 26.417 & 25.351 & 26.084 & 27.231 & 1.500 \\
ROA & 0.032 & 0.009 & 0.039 & 0.076 & 0.120 \\
LEV & 0.443 & 0.295 & 0.453 & 0.586 & 0.197 \\
LOSS & 0.189 & 0 & 0 & 0 & 0.391 \\
INVREC & 0.274 & 0.166 & 0.266 & 0.375 & 0.149 \\
EXPRATIO & 27.688 & 0.328 & 12.611 & 52.771 & 30.725 \\
DA & 0.057 & 0.019 & 0.040 & 0.074 & 0.060 \\
\hline
\end{tabular}

Panel B. insured company sample

\begin{tabular}{lrrrrr}
\hline \multicolumn{1}{c}{ Variable } & Mean & Q1 & Median & Q3 & Std. Dev. \\
\hline LHOUR & 7.512 & 6.856 & 7.378 & 8.114 & 0.908 \\
LFEE & 18.870 & 18.198 & 18.757 & 19.456 & 0.876 \\
LCOV & 4.359 & 3.401 & 3.912 & 5.300 & 1.206 \\
BIG4 & 0.859 & 1.000 & 1.000 & 1.000 & 0.348 \\
SIZE & 27.504 & 26.130 & 27.455 & 28.706 & 1.636 \\
ROA & 0.018 & 0.012 & 0.046 & 0.087 & 0.073 \\
LEV & 0.167 & 0.318 & 0.493 & 0.621 & 0.192 \\
LOSS & 0.154 & 0 & 0 & 0 & 0.361 \\
INVREC & 0.231 & 0.120 & 0.216 & 0.324 & 0.142 \\
EXPRATIO & 32.467 & 0.352 & 23.860 & 59.676 & 32.917 \\
DA & 0.056 & 0.018 & 0.040 & 0.077 & 0.058 \\
\hline
\end{tabular}

Note: LHOUR: natural log of audit hour; LFEE: natural log of audit fees; $D \& O$ : an indicator variable that equals one when the company has D\&O liability insurance and zero otherwise; $L C O V$ : natural log of the insurance coverage limit of D\&O liability insurance; BIG4: an indicator variable that equals one when the audit firm is a Big4 auditor and zero otherwise; SIZE: natural $\log$ of total assets; ROA: ratio of net income to total asset; $L E V$ : total leverage scaled by total assets; $L O S S$ : an indicator variable that equals one when the company's net income is negative and zero otherwise; INVREC: sum of inventories and receivable divided by total assets; EXPRATIO: the ratio of oversea sales to total sales; $D A$ : absolute value of discretionary accruals calculated by Kothari et al. (2005).

\subsection{Multivariate Analysis for Hypothesis 1}

Table 3 presents the regression results for testing hypothesis. This study examines the association between D\&O liability insurance and audit effort. Audit hours and fees are used as proxies for audit effort. In column (1) of Table 3, the dependent variable is the natural $\log$ of audit hours $($ LHOUR $)$. The coefficient of $D \& O$ is $0.198(\mathrm{t}=$ 7.68), which is significant at the $1 \%$ level. This result indicates that when clients have D\&O liability insurance, auditors perceive a higher litigation risk and therefore spend more time performing the audit in order to reduce their audit risk. The coefficients for $B I G 4, S I Z E$, and $L E V$ are positive and significant, implying that these factors have a significant effect on audit hours. The coefficients for ROA and EXPRATIO are negative and not significant. Values for LOSS, INVREC, and DA are positive and not significant. In column (2) of Table 3, the dependent variable is the natural $\log$ of audit fees $(L F E E)$. The coefficient of $D \& O$ is $0.146(\mathrm{t}=6.94)$, which is significant at the $1 \%$ level, implying that when clients have D\&O liability insurance, auditors charge higher audit fees because they perceive that insured companies have higher litigation risk than uninsured companies. Therefore, auditors charge higher audit fees as a risk premium. The coefficients of BIG4, SIZE, LEV , and LOSS are positive and significant, indicating that these 
variables have a strong effect on audit fees. However, the coefficients of ROA, INVREC, EXPRATIO, and DA are insignificant, indicating that these variables have little effect on audit fees. These results imply that auditors use the information about D\&O liability insurance when they determine their audit hours and fees. According to previous studies, companies with opportunistic managers and weak governance tend to purchase D\&O liability insurance (Chalmers, Dann and Harford, 2002; Lin, Officer, and Zou, 2011). Information about D\&O liability insurance is therefore useful for prediction of litigation risk to third parties.

Table 3. Results for hypothesis 1

\begin{tabular}{l|c|c}
\hline \multicolumn{1}{c|}{ Variable } & LHOUR & LFEE \\
\hline Intercept & $-3.614(14.74)^{* * *}$ & $7.109(35.59)^{* * *}$ \\
D\&O & $0.198(07.68)^{* * *}$ & $0.146(06.94)^{* * *}$ \\
BIG4 & $0.272(11.36)^{* * *}$ & $0.083(04.26)^{* * *}$ \\
SIZE & $0.386(41.21)^{* * *}$ & $0.412(54.01)^{* * *}$ \\
ROA & $-0.164(-1.52)$ & $0.045(00.52)$ \\
LEV & $0.117(01.90)^{*}$ & $0.303(06.04)^{* * *}$ \\
LOSS & $0.053(01.62)$ & $0.047(01.79)^{*}$ \\
INVREC & $0.036(00.42)$ & $0.074(01.07)$ \\
EXPRATIO & $-0.000(-0.69)$ & $-0.001(-3.08)^{* * *}$ \\
DA & $0.247(01.39)$ & $0.119(00.82)$ \\
\hline Year Dummy & Included & Included \\
Industry Dummy & Included & Included \\
Number of observations & 2,026 & 2,026 \\
Adj R. & 0.696 & 0.768 \\
\hline
\end{tabular}

Note: t-statistics are reported in bracket. ${ }^{* * *},{ }^{* *},{ }^{*}$ indicate, respectively, the significance level at the $1 \%, 5 \%$ and $10 \%$ level or better. See the note of Table 2 for the definitions of the variables.

\subsection{Multivariate Analysis for Hypothesis 2}

Table 4 presents the results of testing of the association between the insurance coverage limit of D\&O insurance and audit effort. Insurance coverage limit indicates how much litigation risk companies cover. Therefore, auditors use information about $\mathrm{D} \& \mathrm{O}$ liability insurance as a proxy for estimating litigation risks. In column (1) of Table 4, the dependent variable is the natural log of audit hour (LHOUR). Our variable of interest is the insurance coverage limit of $\mathrm{D} \& \mathrm{O}$ insurance ( $L C O V$ ). The coefficient of $L C O V$ is $0.079(\mathrm{t}=3.52)$, which is significant at the $1 \%$ level. In column (2) of Table 4, the dependent variable is the natural log of audit fees (LFEE), and the coefficient of LCOV is $0.110(\mathrm{t}=5.70)$, which is significant at the $1 \%$ level. Through these results, this study provides evidence that auditors use insurance information when they provide auditing service. Auditors spend more time performing audits and charge higher audit fees when their clients has higher coverage limit of D\&O insurance. Total number of observations for insured companies are 726 in the Table 1, but 30 of them fail to disclose insurance coverage limit. Finally, 696 observations are used for testing hypothesis 2 .

Table 4. Results for Hypothesis 2

\begin{tabular}{|c|c|c|}
\hline Variable & LHOUR & LFEE \\
\hline Intercept & $-4.697(-10.91)^{* * *}$ & $6.660(18.03)^{* * *}$ \\
\hline$L C O V$ & $0.079(3.52)^{* * *}$ & $0.110(5.70)^{* * *}$ \\
\hline$B I G 4$ & $0.357(6.52)^{* * *}$ & $0.123(2.60)^{* * *}$ \\
\hline SIZE & $0.418(23.36)^{* * *}$ & $0.414(26.97)^{* * *}$ \\
\hline$R O A$ & $-0.370(-1.09)$ & $0.507(1.75)^{*}$ \\
\hline$L E V$ & $-0.192(-1.68)^{*}$ & $0.141(1.43)$ \\
\hline LOSS & $0.023(0.36)$ & $0.042(0.76)$ \\
\hline INVREC & $0.442(2.70)^{* * *}$ & $0.449(3.19)^{* * *}$ \\
\hline EXPRATIO & $-0.001(-1.09)$ & $-0.002(-2.93) * * *$ \\
\hline$D A$ & $0.251(0.79)$ & $0.032(0.12)$ \\
\hline Year Dummy & Included & Included \\
\hline Industry Dummy & Included & Included \\
\hline Number of observations & 696 & 696 \\
\hline Adj. R & 0.754 & 0.806 \\
\hline
\end{tabular}

Note: t-statistics are reported in bracket. ${ }^{* * *},{ }^{* *},{ }^{*}$ indicate, respectively, the significance level at the $1 \%, 5 \%$ and $10 \%$ level or better. See the note of Table 2 for the definitions of the variables. 


\subsection{Additional Test}

According to Table 2, 68.6\% of companies in total sample hire Big4 auditors. Even though we include a control variable of BIG4, it is difficult to control the effects of Big4 auditors perfectly. In general, Big4 auditors spend more time and charge higher fees for their services due to their reputation (Palmrose, 1986). To remove the Big4 effect, we divide the sample into "companies audited by Big4 auditors" and "those not audited by Big4 auditors". In Table 5, columns (1) and (2) present the results of testing of the association between D\&O liability insurance and Big4 auditors' effort. In column (1), the dependent variable is audit hours (LHOUR). The coefficient of $D \& O$ is $0.202(\mathrm{t}=6.66)$, which is significant at the $1 \%$ level. In column $(2)$, the dependent variable is audit fees (LFEE). The coefficient of $D \& O$ is $0.136(\mathrm{t}=5.70)$, which is significant at the $1 \%$ level. In columns (3) and (4), the results for the association between D\&O liability insurance and Non-Big4 auditors' effort are listed. In columns (3) and (4), the coefficients of $D \& O$ are $0.131(\mathrm{t}=3.68)$ and $0.152(\mathrm{t}=3.64)$, respectively, which are significant at the $1 \%$ level. Both Big4 and Non-Big4 auditors spend more time and charge higher audit fees for insured companies due to their perception that the litigation risk is higher for the insured companies than for uninsured companies.

Table 5. Results for additional test

\begin{tabular}{l|cc|cc}
\hline \multirow{2}{*}{ Variable } & \multicolumn{3}{c}{ BIG4 } & \multicolumn{2}{c}{ NON-BIG4 } \\
\cline { 2 - 5 } & $\mathbf{( 1 ) L H O U R}$ & $\mathbf{( 2 ) L F E E}$ & $\mathbf{( 3 ) L H O U R}$ & $\mathbf{( 4 ) L F E E}$ \\
\hline Intercept & $-4.125(-14.12)^{* * *}$ & $6.391(27.83)^{* * *}$ & $0.483(00.92)$ & $10.901(24.24)^{* * *}$ \\
\& $O$ & $0.202(06.66)^{* * *}$ & $0.136(05.70)^{* * *}$ & $0.131(03.68)^{* * *}$ & $0.152(03.64)^{* * * *}$ \\
SIZE & $0.414(37.80)^{* * *}$ & $0.442(51.37)^{* * *}$ & $0.228(11.17)^{* * *}$ & $0.263(15.06)^{* * *}$ \\
ROA & $-0.204(-1.26)$ & $0.010(00.32)$ & $-0.108(-0.81)$ & $0.067(00.58)$ \\
LEV & $0.069(00.85)$ & $0.169(02.62)^{* * *}$ & $0.112(01.24)$ & $0.374(04.83)^{* * *}$ \\
LOSS & $0.051(01.19)$ & $0.057(01.68)^{*}$ & $0.024(00.51)$ & $0.020(00.50)$ \\
INVREC & $0.129(01.15)$ & $0.258(02.94)^{* * *}$ & $0.061(00.49)$ & $-0.050(-0.47)$ \\
EXPRATIO & $-0.000(-1.10)$ & $-0.000(-1.84)^{*}$ & $0.001(02.21)^{* *}$ & $-0.000(-0.71)$ \\
DA & $0.316(01.40)$ & $0.149(00.84)$ & $0.046(00.17)$ & $-0.049(-0.08)$ \\
\hline Year Dummy & Included & Included & Included & Included \\
Industry Dummy & Included & Included & Included & Included \\
N. of obs. & 1,389 & 1,389 & 637 & 637 \\
Adj. R & 0.694 & 0.797 & 0.290 & 0.419 \\
\hline
\end{tabular}

Note: $\mathrm{t}$-statistics are reported in bracket. $* * *, * * *$ indicate, respectively, the significance level at the $1 \%, 5 \%$ and $10 \%$ level or better. See the note of Table 2 for the definitions of the variables.

\section{CONCLUSION}

This study examines the association between D\&O liability insurance and audit effort. It provides evidences as to whether auditors use D\&O liability insurance information when they set the amount of their audit effort. We find that auditors adjust their audit hours and fees when their clients carry D\&O liability insurance. For clients with more expensive D\&O liability insurance, auditors spend more time in order to minimize their audit risk and they also charge higher audit fees as a risk premium.

This study, however, may have limitations under following caveats. First, there is the possibilities of that the empirical results are depended on measurement criteria or time period. There may be other omitted factors which bias the empirical results. Second, our firm-year observations are constrained by the availability of D\&O liability insurance, and thereby it may contain a bias that the observations are toward relatively large firms where face higher litigation risks. Therefore, it is challenging to say that the results can be generalized into a broader set of observations.

Despite these caveats, this study provides evidence that D\&O liability insurance information is very meaningful and useful to auditors. D\&O liability insurance is not mandatory disclosed as of 2008 in Korea. This study therefore suggests that policy-makers should consider re-mandatory public disclosure of D\&O liability insurance information. 


\section{AUTHOR INFORMATION}

Sohee Woo is a Ph.D. of School of Business at Yonsei University in Korea. Research interests included audit areas, corporate governance, financial management and capital market in accounting. ( $1^{\text {st }}$ author)

Chang Seop Rhee is an assistant professor of School of Business at Sejong University in Korea. Research interests include International Financial Reporting Standard, equity valuation, management earnings forecasts, and other financial \& managerial accounting issues. (Corresponding author)

Sanghee Woo is a master student of School of Business at Sungkyunkwan University. Research interests included corporate governance and hedge fund in emerging markets. (Co-author)

\section{REFERENCES}

Ashbaugh, H., LaFond, R. Z., \& Mayhew, B. (2003). Do non-audit services compromise auditor independence? Further evidence. The Accounting Review 78(3): 611-639.

Chalmers, J.M.R., Dann, L.Y., \& Harford, J. (2002). Managerial opportunism? Evidence from directors' and officiers' insurance purchases. Journal of Finance, 57(2):609-636.

Choi, K., \& Paek, W. (1998). Auditor's types and audit quality: With an emphasis on audit fee and hours. Korean Accounting Association 23(2): 133-161.

Chun, H., \& Rhee, C. S. (2015) Analyst coverage and audit effort: Empirical approach to audit hours. Journal of Applied Business Research. Forthcoming.

Core, J. E. (1997). On the corporate demand for directors' and officers' insurance. Journal of Risk and Insurance 64: 63-87.

Doyle, J., Ge, W., \& McVay, S. (2006). Accruals quality and internal control over financial reporting. Working paper, Utah State University, University of Washington, and New York University.

Fier, S. G., McCullough, K.A., Mansfield, N. R., \& Gabel, J. T. A. (2012). Probability updating and the market for directors' and officers' insurance. SSRN Working Paper.

Ge, W., \& McVay, S. (2005). The disclosure of material weaknesses in internal control after the Sarbanes-Oxley Act. Accounting Horizons 19:137-158.

Gillain, S., \& Panasian, C. A. (2014). On lawsuits, corporate governance, and directors' and officers' liability insurance. Journal of Risk and Insurance. Forthcoming.

Griffith, S.J. (2006). Unleashing a gatekeeper: Why the SEC should mandate disclosure of details concerning directors' and officers' liability insurance policy. University of Pennsylvania Law Review, 154 (5): 1147-1208.

Houston, R. W., Peters, M. F., \& Pratt, J. H. (1999). The audit risk model, business risk and audit-planning decision. The Accounting Review 74(3):281-298.

Kothari, S., Leone, A., \& Wasley, C. (2005). Performance matched discretionary accruals measures. Journal of Accounting and Economics 39: 163-197.

Lin, C., Officer M. S., \& Zou, H. (2011). Directors' and officiers' liability insurance and acquisition outcomes. Journal of Financial Economics 102: 507-525.

Narjess, B., Nabil, G., \& Martin, B. (2008). Managerial opportunism in accounting choice: Evidence from directors' and officers'; liability insurance purchases. SSRN Working paper.

O'Sullivan, N. (2002). The demand for directors' and officers' insurance by large UK companies. European Management Journal 20: 547-583.

Palmrose, Z. (1986). The effect of nonaudit services on the pricing of audit services: Further evidences. Journal of Accounting Research 24 (Autumn): 405-411.

Park, J. I., \& Choi, K. (2009). The effect of abnormal audit fees and audit hours on discretionary accruals. Korean Taxation and Accounting Journal 10: 257-293.

Redington, W. C. (2005). D\&O underwriting implications of Sarbanes-Oxley. International Journal of Disclosure and Governance 2: 151-158.

Reynolds, J.K., \& Francis, J. (2001), "Does size matter? The influence of large clients on office-level auditor reporting decisions", Journal of Accounting an Economics 30: 375-400.

Rhee, C. S., Choi, W. S., \& Bae S. H. (2012). The effect of managers' real earnings management activity on audit hour and audit fee, Korean Management Review, 41(4), 757-787.

Simunic, D. (1980). The pricing of audit services: theory and evidence. Journal of Accounting Research 18:161-190.

St. Pierre, K., \& Anderson, J. (1984). An analysis of the factors associated with lawsuits against public accountants. The Accounting Review 59 (April): 242-263.

Tillinghast-Towers Perrin (2002). Directors and officers liability survey: U.S. and Canadian results. http://www.towersperrin.com. 